\title{
Methods for managing the food value chain
}

\section{Zhanna A. Ermakova, Tatyana V. Andreeva, Raisa S. Vidischeva}

\begin{abstract}
The paper aims to develop the methods for managing the food value chain at the level of a region and business entities. Methodologically, the study rests on the concept of value chains that takes into account the interests of governing bodies and is focused on creating maximum product value for consumers. The research methods are the following: in terms of management purposes at regional level - administrative, economic, dynamic and statistical methods; at the level of business entities - a process approach, integration-based, system-analytical and integrated methods. The authors propose a model of a system for food value chain management that covers the meso- and micro-levels of management united by a common goal, i.e. the creation of maximum value added. The article substantiates the elements of the methods for managing the food value chain, taking into account the ranking of widespread management tools developed by the global management consultancy Bain \& Company. The authors identify the effective methods and tools for managing commodities, as well as production and distribution units of the value chain. We suggest a mechanism for forming a governing body, i.e. a subject of food value chain management using the case study of Orenburg oblast. The research results can be useful for federal and regional authorities, as well as companies' top management engaged in all the units of the food value chain with different industry affiliations.

Keywords: value chain; methods; management system; food industry; Orenburg oblast.

JEL Classification: G30, L66, P42

Funding: the reported study was funded by RFBR, project number 19-010-00050 "Methods for managing the food value chain in a region (the case study of Orenburg oblast)".

Paper submitted: July 26, 2019

For citation: Ermakova Zh.A., Andreeva T.V., Vidischeva R.S. (2019). Methods for managing the food value chain. Upravlenets - The Manager, vol. 10, no. 5, pp. 63-74. DOI: 10.29141/2218-5003-2019-10-5-7.
\end{abstract}

\section{INTRODUCTION}

In the context of economic globalization, constant turmoil and economic sanctions, there arises a necessity to adopt a brand-new approach to managing the food value chain in response to external threats from the European Union in order to ensure food security in Russia.

Being unique in terms of applied technologies, the forms of production organization, material support and commodity provision, the Russian food industry in conjunction with other industries provide consumers with high-quality and affordable food products. At that, the cost of the final product is a key element of management.

The problem of effective management of the production process and distribution of the final food product with maximum return is relevant not only for manufacturers, but also for federal and regional authorities. The issue of effective management of the food value chain in a region is of primary importance, since the level of economic development in a region directly depends on the value added created in its territory.

The purpose of the study is to develop effective methods for managing the food value chain at the level of region and business entities. The existing methods and models of value chain management rest on shaky scientific foundations and require the following objectives to be accomplished:

- to construct a management system model that recognizes not only the industry specificity, but also the economic interests of internal and external chain participants, including end customers of foodstuffs in a particular region;

- to determine the governing body - the subject of food value chain management at regional level and to clarify its managerial functions;
- to establish the referent points for authorities operating at meso- and micro-levels;

- to justify methods and management tools that are effective in managing commodity, production and distribution units of the value chain.

The necessity for theoretical-methodological justification and development of the system for managing the food value chain is due to the following reasons:

- external threats affecting the country's food security;

- growing competition in both domestic and foreign food markets;

- high-tech development of food industry sectors producing high-quality, competitive products that are not inferior to foreign alternatives;

- accelerated development and modernization of agriculture in consequence of solid government support;

- declining importance of state regulation in addressing food security issues.

In this respect, it is relevant to establish an effective system for managing the food value chain at regional level, which will allow to administer production, commodity provision and distribution in an integrated manner.

\section{THEORETICAL FOUNDATIONS}

An analysis of scientific literature reveals that the methodological issues of product value chain management have not yet been adequately investigated. There are numerous interpretations of the term "management methodology"; however, all of them are of general scientific nature and deal with the methodological aspects of management activities exclu- 
sively at the level of business entities, regions or states, while neglecting conceptual principles of value chain management in terms of product of a particular industry [Gerasimov, 2016; Novikov, 2011; Mentzer, Stank, Esper, 2008].

Gerasimov [2016] notes that the central element in resolving complex problems in management is the methodological process aimed at choosing management methods, studying barriers and means to overcome them, and substantiating decisions made. Identifying beneficial points of management actions is a complicated task for the subject of management that requires an effective management mechanism to be developed as an integral part of a management system [Evseeva, 2014]. At that, a management mechanism is a plan of actions on the object of management that ensures the achievement of management goals.

The concept of value chain management proceeds from the assumption that consumer is the principal focus for an enterprise forming the basis for its activities and management as a process of administering the sequence of integrated activities and information about product flows that is aimed at creating maximum product value for consumers and ensuring sales efficiency for the enterprise 1.

Michael Porter, Gary Gereffi, Raphael Kaplinsky and Mike Morris are among internationally recognized experts in the field of value chains. In their numerous works, the researchers address the theoretical-methodological aspects of the analysis of value chains for gaining the competitive advantages by business entities both domestically and internationally in the conditions of rapid economic globalization [Porter, Sampler, Prahalad, 2007; Porter, 1985; Gereffi, Korzeniewicz, 1994; Kaplinsky, Morris, 2002; Gereffi, Kaplinsky, 2001].

Some foreign scholars state that, in order to function effectively, the value chain requires a certain degree of "management". However, science pays too little attention to the methodological tools of management.

In their book The Portable MBA in Strategy [2007], Porter, Sampler and Prahalad interpret the effective value chain management as an improvement in:

- management targeted at particular activities in order to maximize use value, reduce costs and investments in assets;

- management of internal integration of activities through, for example, enhancing product quality while reducing costs incurred in the process;

- management of external integration of an individual organization's value chain with the chains of suppliers, customers and other participants with a view to increasing the product value while reducing costs.

Gereffi and Kaplinsky [2001] distinguish between three forms of value chain management, but there is no clear consensus among scholars about their existence:

- legislation management implemented by both internal participants and government bodies involved in the chain through establishing certain regulations, standards and requirements (for example, for suppliers);

\footnotetext{
'Value chain management. Available at: http://econom-lib.ru/3-21. php.
}

- supervisory management, including control over meeting the terms of supply, as well as labour, environmental and quality standards;

- executive management that provides both internal and external support for the chain's participants in terms of fulfilling the requirements and complying with the rules.

Further studies within the framework of control theory performed by Gereffi [1999] identify two types of value chains depending on their role in management - producerdriven chains and buyer-driven chains.

Andreeva and Ermakova [2011] divide producer-driven chains into two categories:

- chains driven by suppliers (producers) of commodities;

- chains driven by final product manufacturers.

Gereffi's findings underlie the research on the value chains in the Russian pipe and furniture industries [Avdasheva, Budanov, Golikova, Yakovlev, 2005]. The Russian experts have revealed that the controlling actors of the chain were able to both concentrate the largest share of value added and profit and set the proportions in which they were distributed among other participants.

According to the recent foreign studies, theorists and practitioners are shifting their attention towards the chain elements with higher value added that are a part of global value chains and whose development is prioritized in the economic policy of developed and developing countries [Gereffi, 2014; Taglioni, Winkler, 2016; Frederick et al., 2017; Gibbon, Ponte, 2008; Humphrey, Schmitz, 2008; Jurowetzki, Lema, Lundvall, 2018].

The researchers at the Institute of Economics of the Ural Branch of the Russian Academy of Sciences have proposed a methodological approach to analyzing value chains based not only on the identification of the controlling party, but also on the assessment of the effect exerted by technological development [Tatarkin, Bryantseva, Dyubanov, 2014].

In recent years, the influence of rapidly developing information technologies on reconfiguration of the product value chain is widely debated in scientific literature. The fast-paced transition to a digital economy makes the concept of value chains even more relevant and thought-provoking for the scientific community [Dementyev, Ustyuzhanina, Evsyukov, 2018; Chulok, 2009].

Belarusian experts discuss the application of the value chain concept in the context of crisis management of economy to ensure financial stability and competitiveness of participating enterprises. A number of scholars believe that value chain management stimulates changes in the links between certain activities and forms sustainable economic systems at the level of regions and economics sectors [Bykov, Avdeeva, Zezyulkina, 2013; Rezkin, 2016].

Use value of an industry's final product is created by not one enterprise, but by a large number of business entities, whose actions have to be skillfully coordinated. According to the experts of the Saint-Petersburg State University, the top level governing the process of value creation is the system of management that embraces two components: the ideology 
(mission) of a business entity and the management process, including planning, organization, motivation and control.

As management subsystems, Yuldasheva and Yudin [2012] distinguish between five elements forming the human, financial, innovative (technological), logistic and marketing potential. They argue that the central purpose of the management system is effective organization of business processes (supply, manufacturing, sales and distribution, and customer service) that provides the maximum use value, minimum costs and an adequate price for the end consumer.

Thus, the current scientific-methodological developments in the field of product value chain management are not rigid management tools, but more of theoretical-descriptive and analytical approaches that require generalization, systematization and adjustments for the industry specificity.

\section{RESEARCH METHODS AND DATA}

The principal purpose of food value chain management at national level is to ensure food security of the country through accelerating import substitution in relation to agricultural commodities, agricultural and food products. The main indicators of an improvement in government programmes aimed at supporting agriculture and the food industry are:

- output of agricultural products and foodstuffs and investments in fixed assets;

- profitability, average monthly wage, labour productivity, number of jobs.

The indices of agricultural and food production show that there is an emerging trend towards growing agricultural output (Fig. 1). The average growth rate of food production is $104.5 \%$, and agricultural production is $102.7 \%$. Slow growth in agricultural production is largely due to the influence of natural (climatic) factors that are characteristic of horticulture.

The index method applied in statistical monitoring allows evaluating the growth in physical volumes of foodstuffs production in the economic industries under examination. Gross value added (GVA) is the most important cost indicator utilized in the practice of management at national and regional levels. GVA characterizes the efficiency and the actual contribution of economic industries to the creation of gross domestic and regional products.

Table 1 provides values of GVA in agriculture and the food industry at current and comparable prices in 2014-2018.

A comparative analysis of fixed-base and chain-linked growth rates of GVA in agriculture and the food industry indicates that the price factor exerts the dominant influence on GVA growth throughout the entire period under consideration. The values expressed at current prices confirm that over the last five years gross value added in agriculture and the food industry has increased by $19.2 \%$ and $24.3 \%$, respectively. At the same time, fixed-base growth rates at comparable prices demonstrate a rise by only $3.9 \%$ and $5.2 \%$, respectively. Outperforming growth rates of GVA at current prices prove that soaring prices for agricultural and food products resulted in a $15.3 \%$ increase in gross value added in agriculture and a $19.1 \%$ increase in the food industry. A rise in physical volumes of foodstuffs production in the industries under review, confirmed by chain-linked growth rates at comparative prices, provides a slight annual increase in value added, with the exception of agricultural indicators in 2018 (see Table 1).

To manage the food value chain effectively, it is necessary to apply science-based methods (approaches) complying with the requirement of a market economy and allowing for the processes of globalization and digitalization. The research methods were selected according to the preliminary assessment of the existing approaches to management presented in modern economic literature.

According to a system-analytical approach, used in the present study as the main research method, the system of food value chain management is viewed as a combination of interrelated components based on the principles of unity and integrity. For the purposes of managing a value chain, management methods (approaches) are categorized into two levels of impact. Management at the meso-level (region) is implemented by means of administrative, economic and dynamic methods; at the micro-level (the level of business entities) - on the basis of the process approach, as well as integration, system-analytical and integrated methods.

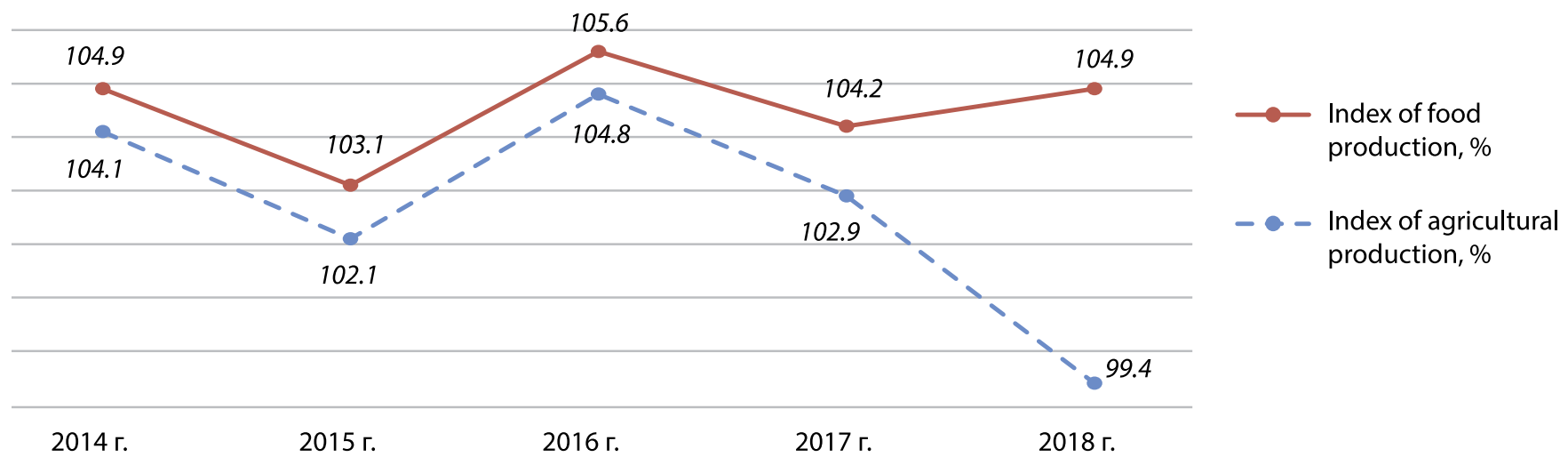

Fig. 1. Indices of agricultural and food production in the Russian Federation in 2014-2018, \% ${ }^{1}$

Рис. 1. Индексы производства продукции сельского хозяйства и пищевой промышленности РФ в 2014-2018 г2., \%

\footnotetext{
${ }^{1}$ Database of the Federal State Statistics Service. Section "National Accounts". Available at: http://www.gks.ru/wps/wcm/connect/rosstat_main/ rosstat/ru/statistics/accounts.
} 
Table 1 - GVA in agriculture and the food industry of the Russian Federation in 2014-2018 Таблица 1 - Валовая добавленная стоимость, созданная в сельском хозяйстве и пищевой промышленности РФ в 2014-2018 г2.

\begin{tabular}{|c|c|c|c|c|c|c|}
\hline \multirow{4}{*}{ Year } & \multicolumn{6}{|c|}{ Gross value added } \\
\hline & \multicolumn{3}{|c|}{ Current prices } & \multicolumn{3}{|c|}{ Comparable prices (2016) } \\
\hline & \multirow{2}{*}{ Total, billion rubles } & \multicolumn{2}{|c|}{ Growth rate, \% } & \multirow{2}{*}{ Total, billion rubles } & \multicolumn{2}{|c|}{ Growth rate, \% } \\
\hline & & Fixed base & Chain-linked & & Fixed base & Chain-linked \\
\hline \multicolumn{7}{|c|}{ Agriculture } \\
\hline 2014 & 2418.2 & 100.0 & - & 2849.2 & 100.0 & - \\
\hline 2015 & 2898.7 & 119.9 & 119.9 & 2890.5 & 101.4 & 101.4 \\
\hline 2016 & 2963.0 & 122.5 & 102.2 & 2963.0 & 104.0 & 102.5 \\
\hline 2017 & 2909.3 & 120.3 & 98.2 & 3018.5 & 105.9 & 101.9 \\
\hline 2018 & 2883.4 & 119.2 & 99.1 & 2959.5 & 103.9 & 98.0 \\
\hline \multicolumn{7}{|c|}{ Food industry } \\
\hline 2014 & 1406.1 & 100.0 & - & 1572.9 & 100.0 & - \\
\hline 2015 & 1507.0 & 107.2 & 107.2 & 1512.9 & 96.2 & 96.2 \\
\hline 2016 & 1604.8 & 114.1 & 106.5 & 1604.8 & 102.0 & 106.1 \\
\hline 2017 & 1642.6 & 116.8 & 102.4 & 1610.5 & 102.4 & 100.4 \\
\hline 2018 & 1747.3 & 124.3 & 106.4 & 1655.0 & 105.2 & 102.8 \\
\hline
\end{tabular}

Calculated by the authors using the data of the Federal State Statistics Service. Available at: http://www.gks.ru/wps/wcm/connect/ rosstat_main/rosstat/ru/statistics/accounts.

Administrative management methods are aimed at regulating the functions, rights, duties and elements of the system of value chain management within the regulatory framework. Economic methods, based on economic laws, are a necessary financial and legal regulator of the interests of all participants in economic relations. Dynamics methods are designed to process the available data array on the activities of participants in the value chain through their systematization and classification with a view to making informed managerial decisions.

The process approach in the system of value chain management is of special importance and is a relatively new tool for initiating effective business processes (activities) that are focused on maximization of the performance indicators of business entities through creation of a product with high use value.

Integration methods of management establish causal relationships between individual elements of the system, as well as the levels and subjects of management, and concentrate on enhancing the effectiveness of their interaction. Integration processes in value chains are aimed at achieving synergistic effects in the form of lower costs incurred in production and distribution of a product, competitive recovery in terms of price and quality, maximization of value for consumers and profit for business structures.

Integrated methods for managing value chains at the level of business entities play a significant part, since they cover technical, technological, economic, social and other aspects of management. Their assessment is extremely important for further planning and development of the participants in value chains.

Management tools (means) aimed at effective regulation of economic processes and relationships between the participants in value chains are among the central elements of the management system. The choice of the value chain management tools at the organization level was based on the findings of the global management consultancy Bain \& Company (USA).

Bain \& Company's 14th Management Tools \& Trends 2013 survey conducted by Darrell Rigby and Barbara Bilodeau [2013] made it possible to rank management tools in order of usability and satisfaction (effectiveness). Over 1,200 executives of large companies in North and Latin America, Europe, the Middle East and the Asia-Pacific region participated in the survey. The respondents were asked to evaluate 25 management tools that Bain \& Company believed to be the most popular.

According to Bain \& Company's survey, the five tools used most often were Strategic Planning, Customer Relationship Management, Employee Engagement, Benchmarking and Balanced Scorecards. The most effective management tools, in respondents' opinion, were Mission and Vision Statements, Strategic Planning, Customer Relationship Management and Core Competencies (Table 2).

\section{RESULTS}

Food value chains, as a new form of economic relationships, consist of specific elements (units) that comprehensively cover the entire product life cycle starting from commodity procurement and production of the final product to selling it to the end consumer (Fig. 2). It is obvious that the relationship between the value chain's units is close, since each of its structural components creates a certain share of value added.

The commodity units of the food value chain encompassing the branches of agriculture provide manufacturing enterprises with primary commodities. Products of horticulture and animal husbandry are the main raw materials for 
Table 2 - Bain \& Company's management tools ranking Таблица 2 - Рейтинг инструментов управления по оченке Bain \& Company

Compiled by the authors based on [Rigby, Bilodeau, 2013].

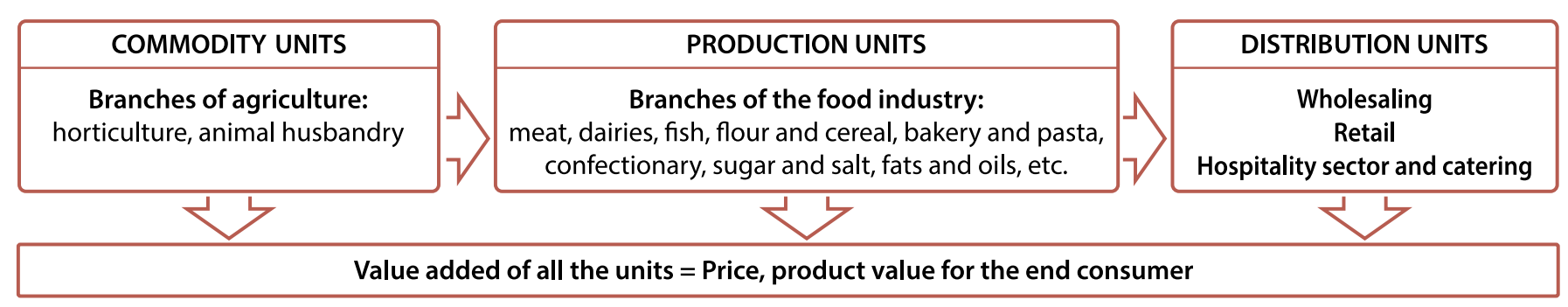

Fig. 2. Industry affiliation of the units of the food value chain

Рис. 2. Отраслевая принадлежность звеньев ценностной цепочки создания стоимости продукта пищевой промышленности

the production units of the value chain of the food industry branches (meat, dairies, flour and cereal, bakery, etc.). The final unit of the chain under discussion is the distribution units, whose activities are aimed at distributing and supplying the consumer with the final product through the wholesale and/or retail distribution network, the hospitality sector and catering.

Similar to any other economic system, the food value chain needs to be manipulated and controlled, which will allow establishing the role and functionality of each participants in the chain.

The authors propose a model of the system of food value chain management (Fig. 3). The model embraces the following components: objectives and levels of management, objects and subjects of management, methods and tools. The logic of the model suggests a gradual transition from one component to another on the way to economic indicators which comprehensively assess the effectiveness of the food value chain.

The process of management is multidimensional and cannot be limited to one single purpose. The integrated methodological approach premised on the concept of value chains helps align the objectives of authorities at meso- and micro-levels.

The main objective, when performing management of the food value chain, is to maximize value added in all units. From the perspective of state and regional governance, the indicated objective is completed through a series of subgoals.
1. The sub-goals at the meso-level are:

- creating conditions for sustainable development of the food industry able to withstand competition from foreign producers and ensure growth in GRP (GDP);

- ensuring food security of a region (country), import substitution in raw material and production units. This aspect needs to be developed due to the fact that the Russian Federation is rich in natural resources and, therefore, it is extremely important to actively restore and develop the country's commodity and production base;

- providing the population of the region (country) with high-quality foods at affordable prices, including those covered in the consumer basket. This goal can be regarded as implementation of a social function of the federal and regional authorities, which is paramount for both developed and developing nations.

2. At the micro-level, the goals of the system of food value chain management are the following:

- generating profit through the production of a food product with high value added. Oftentimes, the foodstuffs produced in the region are not delivered to end consumers locally, but sold outside the region as a semi-finished product with a minimum value added. For example, sunflower oil produced in Orenburg oblast does not practically come into the local market, but is sold to other regions as raw material (or semi-product) for further processing and production of branded finished products with high value added;

- introducing a food product with maximum use value and minimum costs incurred in its production and sale. The 


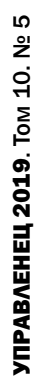

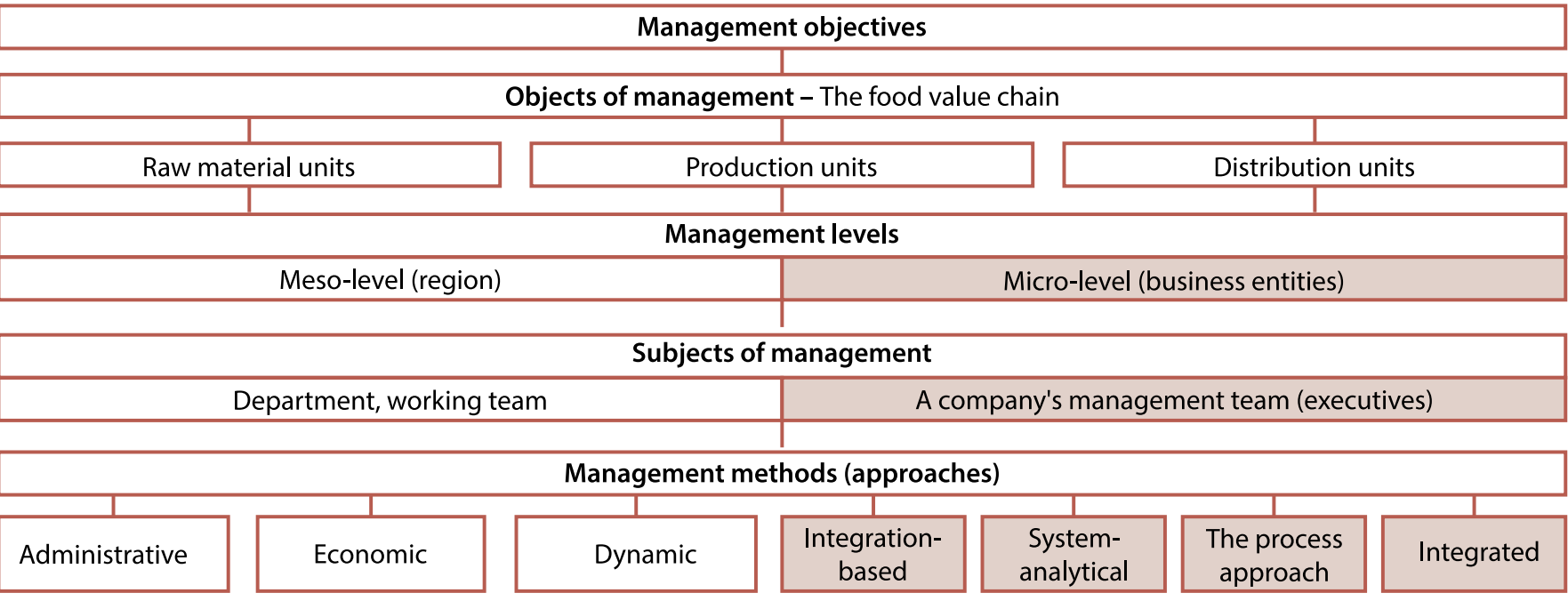

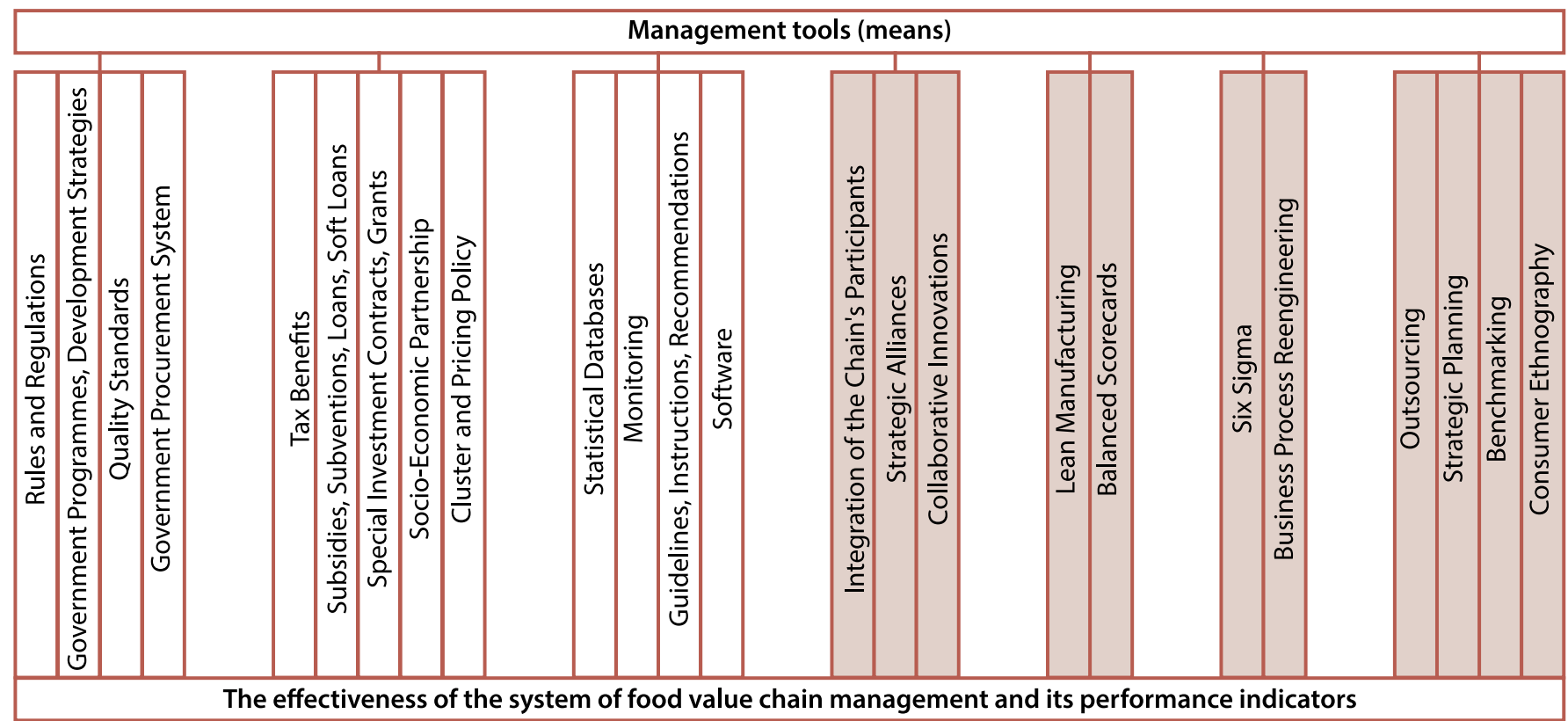

Fig. 3. Model of the system of food value chain management

Рис. 3. Модель системы управления ценностной цепочкой создания стоимости продукта пищевой промышленности

\begin{tabular}{|c|c|c|}
\hline \multicolumn{3}{|c|}{ Meso-level (region) } \\
\hline $\begin{array}{c}\text { Creating conditions for sustainable } \\
\text { development of the food industry able } \\
\text { to withstand competition from foreign } \\
\text { producers and ensure growth in GRP (GDP) }\end{array}$ & $\begin{array}{c}\text { Ensuring food security of a region } \\
\text { (country), import substitution } \\
\text { in commodity and production units }\end{array}$ & $\begin{array}{c}\text { Providing the population of the region } \\
\text { (country) with high-quality foods } \\
\text { at affordable prices, including those } \\
\text { covered in the consumer basket }\end{array}$ \\
\hline \begin{tabular}{|l|l|}
\hline Mrofit-making through the production \\
of a food product with high value added
\end{tabular} & $\begin{array}{c}\text { Introducing a food product with maximum } \\
\text { use value and minimum costs incurred } \\
\text { in its production and sale }\end{array}$ & $\begin{array}{c}\text { Enhancing the quality and competitiveness } \\
\text { of a food product and integrating } \\
\text { into global supply chains }\end{array}$ \\
\hline
\end{tabular}

Fig. 4. Relationships between the objectives of the system of food value chain management at meso-and micro-levels Рис. 4. Взаимосвязь целей системы управления ценностной цепочкой создания стоимости продукта пищевой промышленности на мезо- и микроуровнях 
fulfilment of this goal is attributed to scientific, technical, technological, software and marketing development of the food value chain units, which is impossible without the introduction of scientific and technological advances and best practices;

- enhancing the quality and competitiveness of a food product and integrating into global supply chains. A high level of competitiveness of a food product capable of entering the competition with foreign manufacturers provides an increase in value added, which, in turn, results in the growth of the region's economy (GRP) and the country's economy at large (GDP).

When it comes to the system of food value chain management, it is necessary to identify the subjects of management, which are categorized according to the level of management (Fig. 3).

1. At the micro-level, the subject of management is the company's management team (executives) that directly controls the process of creating a food product's value for end consumers through regulation of economic relationships between all the participants in the corporate entity.

2. At the meso-level, the subject of management is a department or a working team (with limited budget funds for its financial support). The mechanism for forming a regional governing body as the subject of food value chain management using the case study of Orenburg oblast is presented in Fig. 5.

Based on an analysis of the organizational structures of Orenburg oblast's Ministries, we have identified departmental units that could be involved in the regional management of the food value chain:

1) the Ministry of Agriculture, Food and Processing Industry of Orenburg oblast, including the Departments for Horticulture, Animal Husbandry, Food and Processing Industry;

2) the Ministry of Finance of Orenburg oblast, including the Department for Budget Policy in Economic Sectors;

3) the Ministry of Economic Development, Industrial Policy and Trade of Orenburg oblast, including the Office for the

\begin{tabular}{|c|c|c|}
\hline $\begin{array}{c}\text { Ministry of Agriculture, Food and Processing } \\
\text { Industry of Orenburg oblast }\end{array}$ & $\begin{array}{c}\text { Ministry of Finance } \\
\text { of Orenburg oblast }\end{array}$ \\
\hline $\begin{array}{c}\text { Department } \\
\text { for Horticulture }\end{array}$ & $\begin{array}{c}\text { Department } \\
\text { for Animal } \\
\text { Husbandry }\end{array}$ & $\begin{array}{c}\text { Department } \\
\text { for Food } \\
\text { and Processing } \\
\text { Industry }\end{array}$ \\
for Budget Policy \\
in Economic Sectors
\end{tabular}

\begin{tabular}{|c|c|c|}
\hline \multicolumn{3}{|c|}{$\begin{array}{c}\text { Ministry of Economic Development, } \\
\text { Industrial Policy and Trade of Orenburg oblast }\end{array}$} \\
\hline $\begin{array}{c}\text { Office } \\
\text { for the Consumer } \\
\text { Market } \\
\text { Development }\end{array}$ & $\begin{array}{c}\text { Department } \\
\text { for Industrial } \\
\text { Development }\end{array}$ & $\begin{array}{c}\text { Department } \\
\text { for Trade, Food } \\
\text { and Services }\end{array}$ \\
\hline
\end{tabular}

Functions of food value chain management implemented by the Departments of the Ministries

- Monitoring of prices for agricultural products and food;

- interacting with processing enterprises and grain producers;

- implementing measures to develop direct relations between producers and con sumers of agricultural products;

- forecasting, current and long-term planning for the development of agribusiness in the region

- Participating in the production of long-
term and short-term forecasts of the func-
tioning of the region's economy;
- working out measures, in concert with
executive bodies of Orenburg oblast, to
improve the state of settlements be-
tween business entities;
- providing information-analytical and
methodological support for the imple-
mentation of the regional budget

- Maintaining a register of strategies and integrated programmes for the socioeconomic development of municipalities; - ranking the region's municipalities according to their socio-economic development;

- analyzing the state of entrepreneurship and the effectiveness of the measures of government support

\section{Working team as the subject of food value chain management}

Additional functions of the working team in managing food value chain:

- monitoring of the state of agriculture, the food industry and food trade in the region;

- implementation and control over the government programmes aimed at developing agriculture, the food and processing industries, and food markets of the region;

- creation of organizational-economic conditions for sustainable development and effective interaction between the participants (business entities) in the food value chain in the region;

- regulating integration processes within the food value chain and assistance in the formation of vertically integrated structures (including clusters) in the region;

- consolidation of the data on the needs of the domestic food market and production capabilities of regional food enterprises;

- assistance in fulfilling the export potential of regional producers of agricultural commodities and food products;

- enhancing the information support for business entities acting as commodity, production and trade units of the food value chain about the future measures and activities to be taken within food, investment, tax, pricing, credit and social policies of the region;

- formulating methodological recommendations and providing information support for the regional participants in the food value chain; - forming the single information-statistical base that allows managing the entire food value chain in the region

Fig. 5. The mechanism for forming the regional governing body - the subject of food value chain management (the case study of Orenburg oblast)

Рис. 5. Механизм формирования регионального управляющего органа - субъекта управления ценностной цепочкой создания стоимости продукта пищевой промышленности (на примере Оренбургской области) 
Consumer Market Development, the Department for Industrial Development and the Department for Trade, Food and Services.

The proposed version of the working team will be existing nominally due to the lack of budget funding, that is, there is no need to set up a special department and office. An employee of each department mentioned above will be a member of the working team while holding down their current jobs. The full scope of the functions assigned to the working team is given in Fig. 5 .

It is noteworthy that there are no universal management methods and tools equally effective in relation to both economic entity and the region. In each specific situation, one or another approach is acceptable that will help maximize all or most of the effective indicators.

1. At the meso-level of food value chain management, the following management methods and tools can be applied.

1.1. Administrative methods and tools are implemented through normative legal acts, government programmes, development strategies, quality standards, the public procurement system, etc.

Normative legal acts, which regulate business entities and their activities in the territory of the entire country or an individual region, serve as effective regulators ensuring the unity of actions when managing certain units of the chain. The corresponding ministries and divisions produce a list of regulatory documents focused on various spheres of the food value chain's activities.

Government programmes and regional development strategies are worked out in order to develop commodity and production units of the food value chain. The most significant initiative is the State Programme for Agricultural Development and Regulation of Agricultural Products, Commodities and Food Markets approved by the Decree of the RF Government of July 14, 2017 no. 717 (as amended of February 2, 2019).

Quality standards are an integral part of the food production process, since food safety is directly dependent on their quality. Government control over the food production process added impetus for the development of quality management systems that ensure food safety at all stages of production. The system of food value chain management is founded on the principles of Hazard Analysis and Critical Control Point (HACCP). The principles themselves are not standards, but they serve as the basis for international and national standards: ISO 22000:2005 is a food safety management system that imposes certain requirements for all business entities operating within the chain of food production and consumption; ISO/TS 22002-1:2009 and ISO 22000:2005 is a prerequisite programme that specifies requirements for food safety and controls the production process of a food product in the Russian Federation; ISO/TS 22003:2007 is the national standard of the food safety management system that sets out requirements for bodies providing audit and certification of food safety.

The government procurement system is regulated by the Federal law no. 44-FZ "On the contract system of the federal and municipal procurement of goods, works and services" and the Federal law no. 223-FZ "On purchases of goods, works and services by certain types of legal entities" and acts as an effective tool of food value chain management, for it encourages the development of market relations and expands the market for selling the food product manufactured.

1.2. Economic methods and tools are implemented through tax benefits to business entities, subsidies, subventions, earmarked loans, soft loans, grants, special investment contracts, socio-economic partnerships, cluster and pricing policies.

Grants received by the units of the value chain are substantial financial support for manufacturers of agricultural and food products. For example, within the framework of the government program "Agricultural Development and Regulation of Agricultural Products, Commodities and Food Markets in Orenburg oblast", beginning farmers, heads of family livestock farms and agricultural consumer cooperatives take part in the annual competition for grants.

Special investment contracts are a specific form of interaction between business entities and public authorities. The Municipal Administration and the economic entity conclude an investment agreement that stipulates that each party takes on mutual obligations. For example, the obligation of the administration is to provide municipal support in the form of benefits for the payment of local taxes or special conditions for the use of land. The business entity bears the following responsibilities: to produce certain economic results characterizing the effectiveness of the investment contract.

Another effective form of mutually beneficial cooperation between businesses and regional authorities is a socioeconomic partnership aimed at consolidating the available resources and fulfilling strategic goals by all the participants in the value chain [Ermakova, Trishkina, 2011].

Cluster policy as an element of industry-specific and regional policy strengthens the relationships between the units of the value chain when implementing large-scale projects that cannot be completed by a single company. The clustering process in the agro-industrial complex and the food industry plays an instrumental socio-economic role, which implies an extensive use of production capacities, increasing job numbers, boosting employee income, enhancing the efficiency of business entities and tax revenues to the treasury [Korabeynikov, Ermakova, Sinyukov, 2013].

1.3. Dynamic methods and tools in the system of food value chain management are implemented through building up statistical databases, monitoring, developing guidelines, instructions and recommendations, as well as adopting specialized management software solutions.

2. At the micro-level, food value chain management is expedient to be implemented by means of the process approach, as well as integration, system-analytical and integrated methods.

2.1. Integration methods are adopted through the use of such management tools as integration of the partici- 
pants of the value chain, creation of strategic alliances and implementation of joint innovations.

Strategic alliances as a form of global cooperation stimulate the participants in various units of the value chain to employ new technology and initiate joint innovative projects. Such cross-company interaction helps overcome borders between regions and even countries, share possible risks and benefits with partners, timely adapt to constantly changing business environment and withstand tough competition.

2.2. System-analytical methods incorporate such management tools as lean manufacturing and balanced scorecards.

Failure to put their vision of the process of food value chain management into practice and track the functioning of its individual components is the fundamental problem for the regional food industry which, if unresolved, makes all other measures ineffective and useless. The balanced scorecard system can contribute the most to the solution of this problem. Its main objective is to transform a strategy into specific tasks and indicators and establish relationships between them which is virtually impossible to do using other tools [Norton, Kaplan, 2010].

2.3. The process approach to food value chain management is implemented via the following tools: reengineering of business processes and the concept of Six Sigma. To achieve the best possible results, the resources and the activity in which they are involved should be conceived as a business process.

Six Sigma tools significantly contribute to ensuring food safety and minimizing the risk of food poisoning, improving productivity and increasing the quality of food products, as well as reducing the production cycle time, waste and costs'.

2.4. Integrated methods of food value chain management suggest applying such tools as outsourcing, strategic planning, benchmarking and consumer ethnography.

Consumer ethnography makes it possible to expand the market for selling the finished food product, modify the production process and improve the management process in order to guarantee the maximum compliance with the population's needs.

The proposed model of the system of food value chain management is incomplete without the assessment of the

\footnotetext{
${ }^{1}$ Six Sigma in the food industry. Available at: http://6sigmas.ru/ industry/promyshlennost/pishchevaya-promyshlennost.
}

indicators characterizing its performance and effectiveness. In this regard, the indicators describing the quality of food value chain management must be determined:

- achievement of goals established by each subject of management;

- production of a sufficient volume of high-quality and safe food products that fully satisfy the needs of the population;

- maximization of value added at all management levels.

The aforementioned results represent the solid basis for further research on the development of the method for assessing the performance and effectiveness of methodological tools used in food value chain management at the mesoand micro-levels.

\section{CONCLUSION}

The developed model of the system food value chain management allows performing effective management of commodity, production and distribution units at the level of both the region and business entity.

Using an integrated methodological approach based on the concept of value chains, the authors have discovered the interconnections between the goals of governing bodies aimed at maximizing value added at the meso- and micro-levels. Sustainable growth in value added in all units of the value chain not only contributes to profit-making by commercial enterprises, but also ensures the development of regional economic industries through an increase in gross regional product that exerts a direct impact on the country's main macroeconomic indicator - gross domestic product.

A wide range of methods (approaches) and tools used in the model of food value chain management will cover the main spheres of management activities aimed at increasing the product value for the end user, competitiveness, efficiency and sustainability of food production development, as well as the organization of mutually beneficial relationships between the participants in the value chain.

The paper has proposed the methods for food value chain management that outline the realities of market, innovation and digital economy of the 21st century. These tools are economically grounded and can be used in the management practice of business entities and regional authorities and serve as the basis for further development of management theory.

Avdasheva S.B., Budanov I.A., Golikova V.V., Yakovlev A.A. (2005). Modernizatsiya rossiyskikh predpriyatiy v tsepochkakh sozdaniya stoimosti (na primere trubnoy promyshlennosti Rossii) [Modernization of Russian enterprises in value chains (the case study of the Russian pipe industry)]. Ekonomicheskiy zhurnal VShE - The HSE Economic Journal, no. 3, pp. $361-377$.

Andreeva T.V., Ermakova Zh.A. (2011). Formirovanie tsepochek sozdaniya stoimosti produkta $v$ pishchevoy promyshlennosti [Forming product value chains in the food industry]. Vestnik Orenburgskogo gosudarstvennogo universiteta - Vestnik of Orenburg State University, no. 1(120), pp. 108-113. 
Bykov A.A., Avdeeva T.G., Zezyul'kina A.E. (2013). Kontseptsiya tsepochek sozdaniya stoimosti i ee primenenie v antikrizisnom upravlenii [The concept of value chains and its application in crisis management]. Belorusskiy ekonomicheskiy zhurnal - Belarusian Economic Journal, no. 1, pp. 32-45.

Gerasimov B.N. (2016). Metodologiya upravleniya: osnovaniya, predposylki, soderzhanie [Management methodology: Grounds, preconditions, content]. Ekonomika i biznes: teoriya i praktika - Journal of Economy and Business, no. 12, pp. 18-23.

Dementyev V.E., Ustyuzhanina E.V., Evsyukov S.G. (2018). Tsifrovaya transformatsiya tsepochek sozdaniya tsennosti: «ulybka» mozhet okazat'sya «khmuroy» [Digital transformation of value chains: «smile curve» can become «scowling»]. Zhurnal institutsional'nykh issledovaniy - Journal of Institutional Studies, no. 4, pp. 58-77. DOI: 10.17835/2076-6297.2018.10.4.058077.

Evseeva S.A. (2014). Analiz podkhodov k opredeleniyu sushchnosti mekhanizma upravleniya [Analysis of approaches to determining the essence of the management mechanism]. Problemy sovremennoy ekonomiki - Problems of Modern Economics, no. 2(50), pp.164-167.

Ermakova Zh.A., Trishkina N.I. (2011). Formy sotsialno-ekonomicheskogo partnerstva gosudarstva i biznesa v regione [Forms of socio-economic partnership between the state and business in the region]. Vestnik OGU - Vestnik of Orenburg State University, vol. 8(127), pp. 40-47.

Korabeynikov I.N., Ermakova Zh.A., Sinyukov A.A. (2013). Upravlenie nauchno-tekhnicheskim razvitiem regional'nogo promyshlennogo kompleksa na osnove klasternogo podkhoda [Management of scientific and technical development of a regional industrial complex based on a cluster approach]. Vestnik UrFU. Seriya: Ekonomika i upravlenie - Bulletin of UFU. Economics and Management, no. 2, pp. 47-61.

Novikov D.A. (2011). Metodologiya upravleniya [Management methodology]. Moscow: Librokom.

Norton D., Kaplan R. (2010). The balanced scorecard. Translating strategy to action. (Russ. ed.: Norton D., Kaplan R. Sbalansirovannaya sistema pokazateley. Ot strategii k deystviyu. Moscow: Olimp-Biznes).

Porter M., Sampler J., Prahalad C.K. (2007). The Portable MBA in Strategy. (Russ. ed.: Porter M., Sampler Dzh., Prakhalad S.K. Kurs MBA po strategicheskomu menedzhmentu. Moscow: Alpina Biznes Buks).

Rezkin P.E. (2016). Strategii integratsii tsepochek sozdaniya stoimosti [Strategies for integrating value chains]. Vesnik BDU, no. 3, pp. 71-75.

Tatarkin A.I., Bryantseva O.S., Dyubanov V.G. (2014). Otsenka vliyaniya novykh tekhnologiy na izmenenie tsepochek sozdaniya stoimosti pri pererabotke tsinksoderzhashchego tekhnogennogo syr'ya [Replacement of reserves zinc producers in the Russian Federation based on the recycling of technogenic raw materials]. Ekonomika regiona - Economy of Region, no. 4, pp. 178-188. DOI: 10.17059/2014-4-14.

Chulok A.A. (2009). Prognoz perspektiv nauchno-tekhnologicheskogo razvitiya klyuchevykh sektorov rossiyskoy ekonomiki: budushchie zadachi [Forecast of S\&T development prospects of the key economy sectors in Russia: Future tasks]. Forsayt Foresight, vol. 3, no 3, pp. 30-36.

Yuldasheva O.U., Yudin O.I. (2012). Modelirovanie tsepochki po sozdaniyu potrebitel'skoy tsennosti [Creating consumer value: modeling the chain of its development]. Problemy sovremennoy ekonomiki - Problems of Modern Economics, no. 1(41), pp. 218-222.

Frederick S., Bamber P., Brun L., Cho J., Gereffi G., Lee J. (2017). Korea in Global Value Chains: Pathways for Industrial Transformation. Duke GVC Center, September, 2017.

Gereffi G. (1999). International trade and industrial upgrading in the apparel commodity chain. Journal of International Economics, vol. 48, no. 1, pp. 37-70.

Gereffi G. (2014). Global value chains in a post-Washington Consensus world. Review of International Political Economy, vol. 21, no. 1, pp. 9-37. DOI: https://doi.org/10.1080/09692290.2012.756414.

Gereffi G., Kaplinsky R. (2001). Introduction: Globalisation, value chains and development. IDS Bulletin, vol. 32, no. 3, pp. 1-8.

Gereffi G., Korzeniewicz M. (1994). Commodity chains and global capitalism. Westport, Connecticut; L.: Praeger.

Gibbon P., Ponte S. (2008). Global value chains: From governance to governmentality? Economy and Society, vol. 37, no. 3, pp. 365-392. DOI: 10.1080/03085140802172680.

Humphrey J., Schmitz H. (2008). Inter-firm relationships in global value chains: Trends in chain governance and their policy implications. International Journal of Technological Learning, Innovation and Development, vol. 1, no. 3, pp. 258-282. DOI: 10.1504/IJTLID.2008.019974.

Jurowetzki R., Lema R., Lundvall B.A. (2018). Combining innovation systems and global value chains for development: Towards a research agenda. The European Journal of Development Research, vol. 30, no. 3, pp. 364-388. DOI: 10.1057/s41287-0180137-4.

Kaplinsky R., Morris M. (2002). A handbook for value chain research. IDRC. Available at: http://www.fao.org/fileadmin/user_upload/fisheries/docs/Value_Chain_Handbool.pdf.

Mentzer J.T., Stank T.P., Esper T.L. (2008). Supply chain management and its relationship to logistics, marketing, production, and operations management. Journal ofBusiness Logistics, vol.29, no. 1, pp.31-46.DOI: https://doi.org/10.1002/j.2158-1592.2008. tb00067.x.

Porter M.E. (1985). Competitive advantage. Creating and Sustaining Superior Performance. N.Y.: Free Press.

Rigby D., Bilodeau B. (2013). Management Tools \& Trends 2013. Bain \& Company. Available at: https://www.bain.com/contentas sets/7fac29fadbe14b70967b3d3c8c540a9b/bain_brief_management_tools_26_trends_2013.pdf.

Taglioni D., Winkler D. (2016). Making global value chains work for development. The World Bank. 


\title{
Zhanna A. Ermakova
}

Dr. Sc. (Econ.), Professor, Corresponding Member of the RAS, Rector. Orenburg State University (13 Pobedy Ave., Orenburg, 460018, Russia). E-mail: 56ermakova@mail.ru.

\section{Tatyana V. Andreeva}

Cand. Sc. (Econ.), Head of Economics Dept. Orsk Institute of Humanities and Technology, branch of Orenburg State University (15a Mira Ave., Orsk, 462403, Russia). E-mail: andreeva-orsk@mail.ru.

\section{Raisa S. Vidischeva}

Cand. Sc. (Econ.), Associate Professor of Economics Dept. Orsk Institute of Humanities and Technology, branch of Orenburg State University (15a Mira Ave., Orsk, 462403, Russia). E-mail: vid1185@yandex.ru.

\section{Методический инструментарий управления цепочкой создания стоимости продукта пишевой промышленности Ж.А. Ермакова, Т.В. Андреева, Р.С. Видищева}

\begin{abstract}
Аннотация. В статье освещается формирование методического инструментария как неотъемлемой части системы управления ценностной цепочкой продукта пищевой промышленности на уровне региона и субъектов хозяйствования. Методологической базой исследования послужили положения концепции цепочки создания стоимости, учитывающие интересы управляющих органов и ориентированные на создание максимальной ценности продукта для потребителя. В целях управления на региональном уровне использованы административные, экономические, динамические и статистические методы; на уровне хозяйствующих субъектов - процессный подход, интеграционные, системно-аналитические, комплексные методы. Результатом исследования стала предложенная модель системы управления ценностной цепочкой продукта пищевой промышленности, охватывающая мезо- и микроуровни управления, объединенные единой целью - созданием максимальной добавленной стоимости. Обоснованы элементы методического инструментария управления такой цепочкой, в том числе с учетом рейтинга популярных инструментов управления, составленного международной консалтинговой компанией Bain \& Company. Определены методы и инструменты управленческого воздействия, способствующие эффективному управлению сырьевыми, производственными звеньями ценностной цепочки, а также звеньями дистрибуции. Представлен механизм формирования управляющего органа - субъекта управления ценностной цепочкой продукта пищевой промышленности на примере Оренбургской области. Результаты исследования могут быть применены федеральными и региональными управленческими структурами, а также менеджментом предприятий всех звеньев ценностной цепочки, имеющих разную отраслевую принадлежность.
\end{abstract}

Ключевые слова: цепочка создания стоимости; методический инструментарий; система управления; пищевая промышленность; Оренбургская область.

\section{JEL Classification: G30, L66, P42}

Финансирование: исследование выполнено при финансовой поддержке РФФИ в рамках научного проекта № 19-010-00050 «Методологический инструментарий управления ценностной цепочкой продукта пищевой промышленности в регионе (на примере Оренбургской области)».

Дата поступления статьи: 26 июля 2019 г.

Ссылка для цитирования: Ермакова Ж.А., Андреева Т.В., Видищева Р.С. (2019). Методический инструментарий управления цепочкой создания стоимости продукта пищевой промышленности // Управленец. Т. 10. № 5. С. 63-74. DOI: 10.29141/2218-50032019-10-5-7.

\section{Источники}

Авдашева С.Б., Буданов И.А., Голикова В.В., Яковлев, А.А. (2005). Модернизация российских предприятий в цепочках создания стоимости (на примере трубной промышленности России) // Экономический журнал ВШЭ. № 3. С. 361-377.

Андреева Т.В., Ермакова Ж.А. (2011). Формирование цепочек создания стоимости продукта в пищевой промышленности // Вестник Оренбургского государственного университета. № 1(120). С. 108-113.

Быков А.А., Авдеева Т.Г., Зезюлькина А.Е. (2013). Концепция цепочек создания стоимости и ее применение в антикризисном управлении // Белорусский экономический журнал. № 1. С. 32-45.

Герасимов Б.Н. (2016). Методология управления: основания, предпосылки, содержание // Экономика и бизнес: теория и практика. № 12. С. 18-23.

Дементьев В.Е., Устюжанина Е.В., Евсюков С.Г. (2018). Цифровая трансформация цепочек создания ценности: «улыбка» может оказаться «хмурой» // Journal of Institutional Studies. № 4. C. 58-77. DOI: 10.17835/2076-6297.2018.10.4.058-077.

Евсеева С.А. (2014). Анализ подходов к определению сущности механизма управления // Проблемы современной экономики. № 2(50). С.164-167.

Ермакова Ж.А., Тришкина Н.И. (2011). Формы социально-экономического партнерства государства и бизнеса в регионе // Вестник ОГУ. № 8(127). С. 40-47. 
Корабейников И.Н., Ермакова Ж.А., Синюков А.А. (2013). Управление научно-техническим развитием регионального промышленного комплекса на основе кластерного подхода // Региональная экономика. № 2. С. 47-61.

Новиков Д.А. (2011). Методология управления. М.: Либроком.

Нортон Д., Каплан Р. (2010). Сбалансированная система показателей. От стратегии к действию. М.: Олимп-Бизнес.

Портер М., Самплер Дж., Прахалад С.К. (2007). Курс МВА по стратегическому менеджменту. М.: Альпина Бизнес Букс.

Резкин П.Е. (2016). Стратегии интеграции цепочек создания стоимости // Веснік БДУ. № 3. С. 71-75.

Татаркин А.И., Брянцева О.С., Дюбанов В.Г. (2014). Оценка влияния новых технологий на изменение цепочек создания стоимости при переработке цинксодержащего техногенного сырья // Экономика региона. № 4. C. 178-187. DOI: 10.17059/2014-4-14.

Чулок А.А. (2009). Прогноз перспектив научно-технологического развития ключевых секторов российской экономики: будущие задачи // Форсайт. № 3(11). С. 30-36.

Юлдашева О.У., Юдин О.И. (2012). Моделирование цепочки по созданию потребительской ценности // Проблемы современной экономики. № 1(41). С. 218-222.

Frederick S., Bamber P., Brun L., Cho J., Gereffi G., Lee J. (2017). Korea in Global Value Chains: Pathways for Industrial Transformation. Duke GVC Center, September, 2017.

Gereffi G. (1999). International trade and industrial upgrading in the apparel commodity chain. Journal of International Economics, vol. 48, no. 1, pp. 37-70.

Gereffi G. (2014). Global value chains in a post-Washington Consensus world. Review of International Political Economy, vol. 21, no. 1, pp. 9-37. DOl: https://doi.org/10.1080/09692290.2012.756414.

Gereffi G., Kaplinsky R. (2001). Introduction: Globalisation, value chains and development. IDS Bulletin, vol. 32, no. 3, pp. 1-8.

Gereffi G., Korzeniewicz M. (1994). Commodity chains and global capitalism. Westport, Connecticut; L.: Praeger.

Gibbon P., Ponte S. (2008). Global value chains: From governance to governmentality? Economy and Society, vol. 37, no. 3, pp. 365-392. DOI: 10.1080/03085140802172680.

Humphrey J., Schmitz H. (2008). Inter-firm relationships in global value chains: Trends in chain governance and their policy implications. International Journal of Technological Learning, Innovation and Development, vol. 1, no. 3, pp. 258-282. DOI: 10.1504/ IJTLID.2008.019974.

Jurowetzki R., Lema R., Lundvall B.A. (2018). Combining innovation systems and global value chains for development: Towards a research agenda. The European Journal of Development Research, vol. 30, no. 3, pp. 364-388. DOI: 10.1057/s41287-018-0137-4.

Kaplinsky R., Morris M. (2002). A handbook for value chain research. IDRC. Available at: http://www.fao.org/fileadmin/user_upload/ fisheries/docs/Value_Chain_Handbool.pdf.

Mentzer J.T., Stank T.P., Esper T.L. (2008). Supply chain management and its relationship to logistics, marketing, production, and operations management. Journal of Business Logistics, vol. 29, no. 1, pp. 31-46. DOI: https://doi.org/10.1002/j.2158-1592.2008. tb00067.x.

Porter M.E. (1985). Competitive advantage. Creating and Sustaining Superior Performance. N.Y.: Free Press.

Rigby D., Bilodeau B. (2013). Management Tools \& Trends 2013. Bain \& Company. Available at: https://www.bain.com/contentassets /7fac29fadbe14b70967b3d3c8c540a9b/bain_brief_management_tools_26_trends_2013.pdf.

Taglioni D., Winkler D. (2016). Making global value chains work for development. The World Bank.

\section{Информация об авторах}

\section{Ермакова Жанна Анатольевна}

Доктор экономических наук, профессор, член-корреспондент РАН, ректор. Оренбургский государственный университет (460018, РФ, г. Оренбург, пр. Победы, 13). E-mail: 56ermakova@mail.ru.

\section{Андреева Татьяна Викторовна}

Кандидат экономических наук, заведующий кафедрой экономики. Орский гуманитарно-технологический институт (филиал) Оренбургского государственного университета (462403, РФ, г. Орск, пр. Мира, 15a). E-mail: andreeva-orsk@mail.ru.

\section{Видищева Раиса Сергеевна}

Кандидат экономических наук, доцент кафедры экономики. Орский гуманитарно-технологический институт (филиал) Оренбургского государственного университета (462403, РФ, г. Орск, пр. Мира, 15a). E-mail: vid1185@yandex.ru. 